\title{
EVALUATION OF WEIGHT LOSS AND METABOLIC PROFILE OF OBESE PATIENTS WITH TYPE 2 DIABETES MELLTTUS (DM2) VERSUS NON- DM2 SUBJECTS, ONE AND THREE YEARS AFTER BARIATRIC SURGERY
}

\author{
Avaliação da perda ponderal e perfil metabólico pós-cirurgia bariátrica em pacientes obesos \\ portadores de diabetes mellitus tipo 2 versus não diabéticos
}

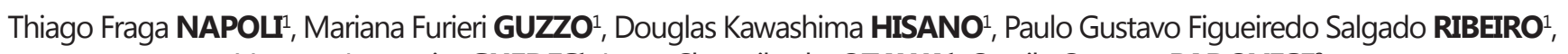
Vanessa Junqueira GUEDES ${ }^{1}$, Joyce Chermikosky OZAWA $^{1}$, Camila Campos PADOVESE²,

Carlos Alberto MALHEIROS ${ }^{2}$, Murilo Rezende MELO $^{3}$, Nilza Maria SCALSSI ${ }^{1}$, Osmar MONTE ${ }^{1}$, João Eduardo SALLES ${ }^{1}$

From the ${ }^{1}$ Endocrinology Unit of the Irmandade da Santa Casa de Misericórdia de São Paulo, Department of Internal Medicine, ${ }^{2}$ Department of Surgery of the Irmandade da Santa Casa de Misericórdia de São Paulo, 'ㄹepartment of Physiology of the Santa Casa de São Paulo Medical School, FCMSCSP, São Paulo, SP, Brazil.

HEADINGS - Diabetes Mellitus. Bariatric surgery. Hemoglobin A, Glycosylated. Weight loss. Lipids

\section{Correspondência: \\ Thiago Fraga Napoli \\ e-mail: napoli38@gmail.com}

Fonte de financiamento: não há

Conflito de interesses: não há

Recebido para publicação: 17/11/2009

Aceito para publicação: 12/01/2010

DESCRTORES - Diabetes Mellitus. Cirurgia Bariátrica. Hemoglobina A glicosilada. Perda de peso. Lipídeos.
ABSTRACT - Background - There is a debate over results obtained from type 2 diabetes mellitus (DM2) obese patients and non-DM2 patients, in reference to metabolic control and ponderal loss, after bariatric surgery. Aim - To evaluate weight loss and metabolic profile of obese patients with DM2 versus non-DM2 subjects, one and three years after bariatric surgery. Methods - Data from 38 non-DM2 patients and 44 DM2 patients submitted to Roux-en-Y gastric-bypass were analysed retrospectively. For the preoperatory, first and third year of post-operatory, were compared: weight, body mass index (BMI), fasting glucose (FG), high density lipoprotein (HDL) and triglycerides (TG). Results - Preoperatively, both groups were statistically equivalent in regards to weight, BMI $(P=$ $0.90)$ and $\mathrm{HDL}(P=0.73)$. This was not the case when TG $(P=0.043)$ and $F G(P<0.01)$ were analyzed. In PO1, both DM2 and non-DM2 groups showed a reduction in weight, BMI and TG, just as FG in the DM2 group $(P<0.05)$. HDL increased $(P<0.05)$ in $P O 1$ in both groups. In the following period, between PO1 and PO3, only TG continued to decrease in the non-DM2 group $(P=0.039)$, while the other variables did not change. In the DM2 group mean $\mathrm{A} 1 \mathrm{c}$ in $\mathrm{PO} 3$ was $6.2 \%+-0.75(\mathrm{P}=0.027)$. It was compared both group's postoperative data. HDL's and TG's variation between groups did not differ in PO1 or between $\mathrm{PO} 1$ and $\mathrm{PO}$. Weight in PO1 and PO3, just as BMI in PO1 and PO3, were not significantly different either. Conclusion - In PO1, weight loss and metabolic improvement was seen in both groups. This was sustained in PO3, with no significant weight regain or lipid/FG change. A1c found suggests a reasonable control of DM2 surgery. A trend towards a less intense weight loss could be noticed in the DM2 group $(P=0.053)$.

RESUMO - Racional - Tem havido debate sobre os resultados obtidos da cirurgia bariátrica nos obesos diabéticos versus não diabéticos, no quesito controle metabólico e perda ponderal. Objetivo - Avaliar a perda ponderal e perfil metabólico dos obesos diabéticos e não diabéticos após um e três anos da cirurgia bariátrica. Método - Análise retrospectiva dos prontuários de 44 diabéticos tipo 2 (DM2) e 38 não-DM2 submetidos à gastroplastia com derivação em Y-de-Roux. Dados como peso, índice de massa corpórea (IMC), glicemia de jejum (GJ), lipoproteína de alta densidade (HDL) e triglicérides (TG) foram vistos no pré-operatório, primeiro (PO1) e terceiro ano (PO3) após a operação. Resultados - No pré-operatório, ambos os grupos foram estatisticamente equivalentes em peso, IMC $(P=0,90)$ e HDL $(P=0.73)$. Não se verificou o mesmo quando TG $(P=0.043)$ e GJ ( $P$ < 0.01) foram analisados. No PO1, ambos DM2 e não-DM2 mostraram redução no peso, IMC e TG, assim como GJ no grupo DM2 $(P<0.05)$. HDL aumentou $(P<$ 0.05) no PO1 em ambos os grupos. No período seguinte, entre PO1 e PO3, somente TG continuou a cair nos não-DM2 diabéticos $(P=0,039)$, enquanto as outras variáveis não mudaram. No grupo DM2, a média da A1c no $P O 3$ foi $6,2 \%+-0,75(P=0,027)$. Compararam-se os dados do pós-operatório de ambos os grupos. A variação de HDL e TG entre os grupos não foi diferente no PO1 e entre PO1 e PO3. Peso no PO1 e PO3, assim como IMC no PO1 e PO3, não foram estatisticamente diferentes. Conclusão - No PO1, perda de peso e melhora metabólica foi vista em ambos os grupos. Este dado foi sustentado no PO3, sem reganho de peso ou alteração lipídica significativa. A Alc encontrada no pós-operatório mostrou bom controle do diabetes pela operação. Houve tendência à menor perda ponderal no grupo DM2 $(\mathrm{P}=0,053)$. 


\section{INTRODUCTION}

I $\mathrm{t}$ is estimated that obesity in the United States doubled between 1980 and 2004, affecting as much as $30 \%$ of the population ${ }^{13}$. Obesity is associated with illnesses such as cardiovascular disease, insulin resistance, hyperinsulinemy, type 2 diabetes mellitus (DM2), dislipidemy and sleep apnea ${ }^{4,11}$. The life expectation of a morbidly obese individual can be reduced by 5 to 20 years. However, bariatric surgery is one possible option for reducing such risk by $35 \%^{2,17}$.

Unfortunately, dietary therapy is relatively ineffective in the long run for obese individuals, and in most cases no more than 5 to $10 \%$ of body weight is lost with dietary restrictions, physical activity and antiobesity medication ${ }^{4,5}$. Currently, bariatric surgery stands out as an effective treatment for obesity. Among several techniques employed, there are specific differences as to their effects in regards to the gastric remainder and alimentary disabsortion ${ }^{11}$. The Rouxen-Y gastric-bypass (RYGB) is the most commonly employed technique being predominantly restrictive ${ }^{11}$.

Bariatric surgery is a highly efficient means of controlling illnesses related to obesity, especially type 2 diabetes mellitus (DM2), which improves before significant weight loss ${ }^{6,14}$. This fact can be explained not only because of the surgery's restrictive effect and a certain level of malabsortion, but also due to the control of the patient's appetite and enteric celerity caused by incretins (GIP and GLP-1), whose release and effect is considerably augmented in DM2 patients submitted to bariatric surgery ${ }^{7}$.

Currently there is a debate over results obtained from DM2 obese patients and non diabetic patients, in reference to metabolic control and ponderal loss, after bariatric surgery.

The aim of the present study was to evaluate weight loss and metabolic profile of non-DM2 obese patients versus DM-2 subjects, one and three years after bariatric surgery.

\section{METHODS}

An observational retrospective cohort study was performed based on the analysis of promptuaries obtained from 38 non-DM2 patients and 44 DM2 patients, classified by age, gender and body mass index (BMI). Between 2001-2006, all patients were submitted to RYGB (a $30 \mathrm{~mL}$ gastric pouch, isolated from the remainder by staples, anastomosed to the distal jejune, which is divided $30 \mathrm{~cm}$ below the Treitz ligament, and the proximal portion is anastomosed to the small bowel $100 \mathrm{~cm}$ below the gastroenterostomy).

For the pre-operative (PREOP), first and third year of post-operative periods (PO1 and PO3), the following variables were compared: weight, $\mathrm{BMI}$, fasting glucose $(F G), H D L, T G$. In the PREOP, both groups were statistically equivalent in regards to weight, $\mathrm{BMI}(\mathrm{P}=$ $0.90)$ and $\mathrm{HDL}(P=0.73)$. This was not the case when TG $(P=0.043)$ and $F G(P<0.01)$ were analyzed. PREOP data is shown in Table 1.

TABLE 1 - Preoperative data of the diabetes type 2 group

\begin{tabular}{|c|c|c|c|}
\hline & DM2 & Non-DM2 & P value \\
\hline Weight $(\mathrm{kg})$ & $124,5 \pm 24,5$ & $124,1 \pm 24,9$ & 0,90 \\
\hline BMI $(\mathrm{kg} / \mathrm{m} 2)$ & $47,2 \pm 8,6$ & $47,55 \pm 8,55$ & 0,90 \\
\hline FG $(\mathrm{mg} / \mathrm{dl})$ & $172,3 \pm 78,4$ & $100,7 \pm 12$ & 0,01 \\
\hline HDL $(\mathrm{mg} / \mathrm{dl})$ & $44,7 \pm 12,7$ & $43,47 \pm 12,83$ & 0,73 \\
\hline TG $(\mathrm{mg} / \mathrm{dl})$ & $213,5 \pm 130$ & $151,6 \pm 73$ & 0,043 \\
\hline Alc $(\%)$ & $9,34 \pm 3,37$ & & \\
\hline Total $(\mathrm{n})$ & 44 & 38 & 82 \\
\hline
\end{tabular}

The statistical analysis were done by T-test or Mann-Whitney test, according to the appropriate characteristics of the individual groups. Statistical significance was considered when $\mathrm{P}<0.05$ was found.

\section{RESULTS}

The non-DM2 group, in $\mathrm{PO} 1$, showed a reduction in weight, BMI $(P<0.001)$ and TG $(P=0.046)$. HDL increased $(P=0.025)$. In the following period, between $\mathrm{PO} 1$ and $\mathrm{PO} 3$, only TG continued to decrease $(\mathrm{P}=0.039)$, while the other variables did not change.

The DM2 group, in $\mathrm{PO} 1$, showed improvement in weight loss, $\mathrm{BMI}$, TG and FG $(\mathrm{P}<0.001)$, and an increase in $\mathrm{HDL}(\mathrm{P}=0.002)$. There was no significant difference in the evaluated parameters between $\mathrm{PO} 1$ and $\mathrm{PO} 3$ (Figures 1 and 2). Mean A1c (Figure 3) in PO3 was $6.2 \%+-0.75$ $(P=0.027)$. Among those exclusively using OAD in PREOP, only one patient continued using oral antidiabetic drugs - OAD - (sulfonylureas or metformin) in PO3. Considering those taking insulin and at least one $O A D$, there were eight patients. In this group, 50\% needed no medication for DM2 control, while $50 \%$ still used at least one OAD. One patient did not discontinue taking insulin.

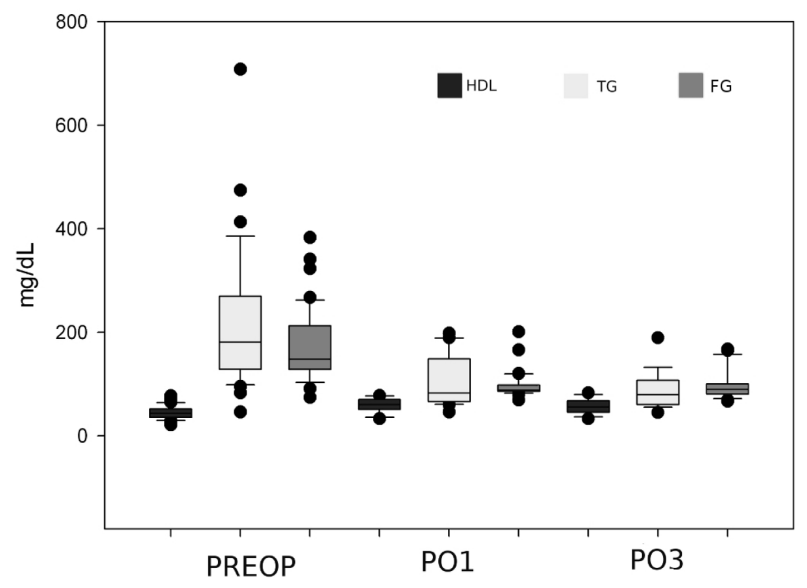

FIGURE 1 - Metabolic profile of the DM2 group in PO1 and PO3. HDL, TG, and FG did not differ between $\mathrm{PO} 1$ and $\mathrm{PO} 3$ 


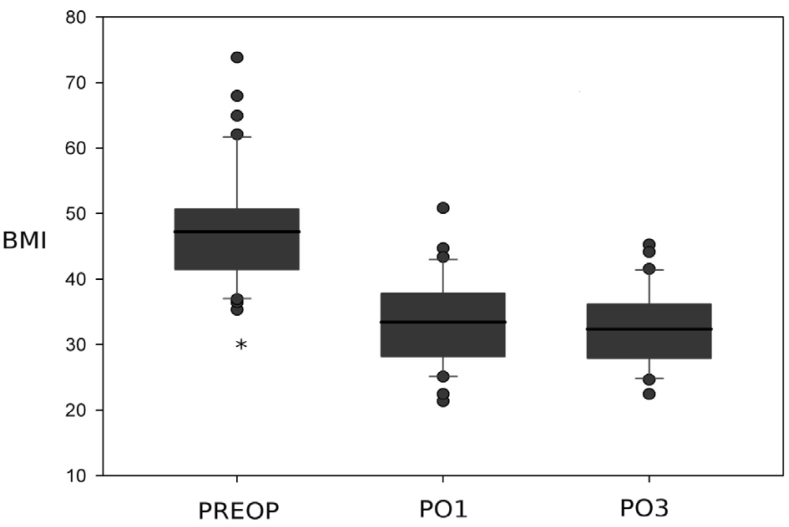

FIGURE 2 - BMI evaluation in DM2 group in PO1 and PO3. There was significant difference between PREOP and PO1 $(P<0.001)$, but not between $\mathrm{PO} 1$ and $\mathrm{PO} 3$

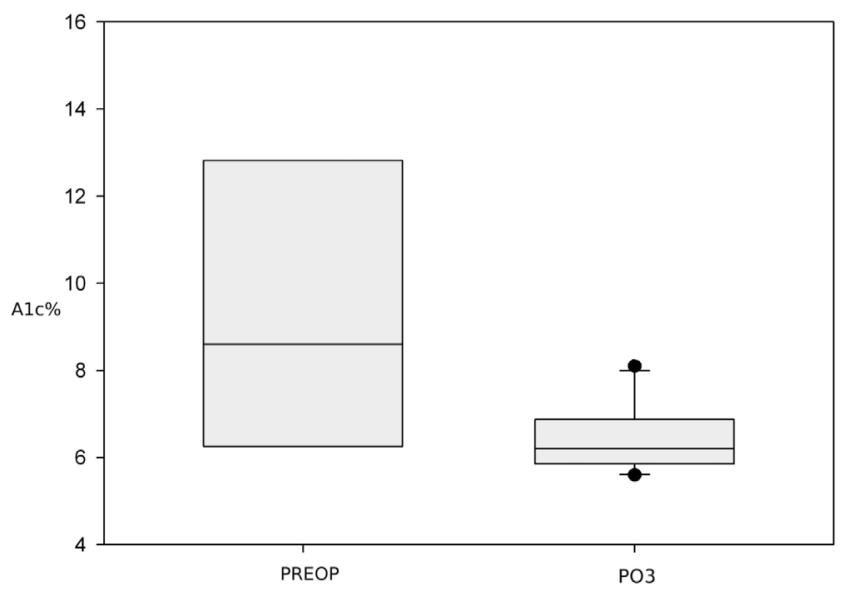

FIGURE 3 - A1C varation between PREOP and PO3 in the DM2 group. There was significant improvement of $\mathrm{Alc}$ $(P=0.027)$. Mean A1c in $P O 3=6.2 \pm 0.75 \mathrm{mg} / \mathrm{dL}$

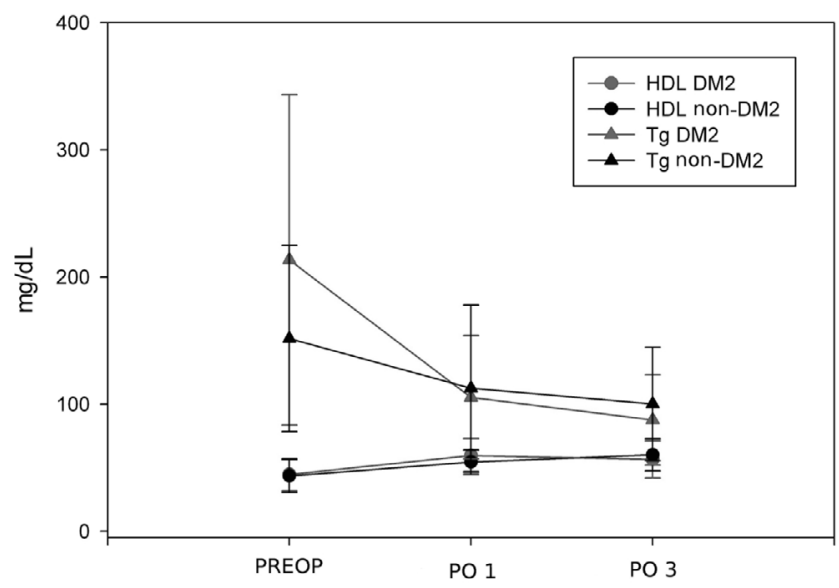

FIGURE 4 - Comparisson of HDL and TG variation between groups. HDL and TG showed significant improvement in both groups in PO1 $(\mathrm{P}<0.05)$. Between PO1 and PO3 TG lowered only in the non DM2 group ( $P=0.039)$, HDL did not change in the same period in both groups
It was compared both group's post-operative data (Figure 4), based on the previous statement of the equivalence between them at baseline concerning weight, BMI and HDL. HDL's variation between groups did not differ in PO1 $(P=0.382)$ or between PO1 and PO3 $(P=0.856)$. The same was found for TG in PO1 $(P=0.057)$ and between $P O 1$ and $P O 3(P=0.772)$. Weight in $\mathrm{PO} 1(\mathrm{P}=0.123)$ and $\mathrm{PO}(\mathrm{P}=0.053)$, just as $\mathrm{BMI}$ in $\mathrm{PO} 1(\mathrm{P}=0.482)$ and $\mathrm{PO} 3(0.113)$, were not significantly different either (Figure 5).

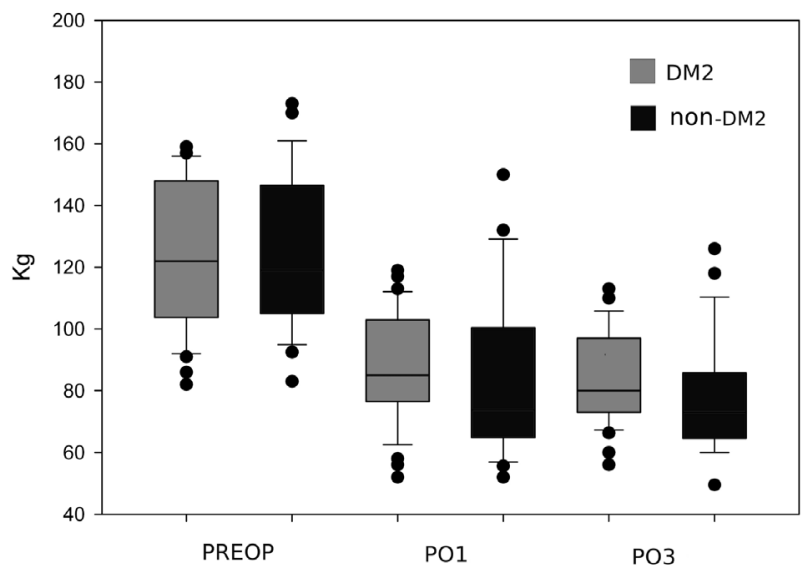

FIGURE 5 - Weight variation in non-DM2 and DM2 groups. Both groups had significant weight loss in $\mathrm{PO} 1$ $(\mathrm{P}<0.001)$. Variation between PO1 and PO3 did not differ comparing both groups

\section{DISCUSSION}

In PO1, weight loss and metabolic improvement could be clearly seen in both groups. This was sustained in $\mathrm{PO}$, with no significant weight regain or lipid/FG change.

Pories et al. ${ }^{12}$ observed sustained diabetes control in $83 \%$ of 608 obese subjects after RYGB, over 9.4 years. There is also evidence that in those who are not entirely relieved of of DM2 symptoms, they experience at least a certain amelioration of the disease $^{4}$.

In this study, the A1c found suggests that reasonable control of DM2 was achieved after surgery although it did not meet the mean values for the non-DM2 population.It was noticed an important decrease in the use of OAD (only one patient used $O A D$ in PO3), which is consistent with the literature ${ }^{15}$. Some factors such as DM2 in PREOP, high A1C and use of insulin were correlated with poor DM2 control post-operatively, while weight loss magnitude and adipose tissue reduction were associated with a wider DM2 improvement ${ }^{15}$.

Other comorbidities, such as arterial hypertension, dyslipidemia, obstructive sleep apnea, showed improvement after RYGB in several studies ${ }^{4,15}$. 
In the present study it was observed sustained lipid profile improvement in PO1 in both groups.

Here, a trend towards a less intense weight loss could be noticed in the DM2 group $(P=0.053)$, which may not have been statistically significant because of the sample's size. This lower weight loss was found in the study by Morínigo et al. ${ }^{10}$. Some studies also indicate that post-operative weight loss did not correlate with DM2's PREOP length, but was inversely proportional to the DM2's severity in PREOP ${ }^{15}$.

Considering the challenge of clinical management of DM2, surgery appears to be a promising treatment for obese DM2. Nevertheless, it is rarely considered an option in clinical algorithms, nor in clinical practice for $\mathrm{DM} 2^{15}$.

Several mechanisms have been proposed for ameliorating DM2 after RYGB. Some studies suggest weight loss, reduced caloric intake, decreased ghrelin, increased PYY and increased secretion of other hormones from the entero-insular axis: incretins, such as GLP-1 and GIP, for subsequent contact between food and the distal small intestine $e^{5,9,15}$.

Incretins play a role in slowing peristalsis and gastric emptying, consequently lowering food intake. They also inhibit glucagon secretion. Collectively, these actions contribute to DM2 control ${ }^{6,9,15}$. Another positive contribution of incretin involves increasing insulin secretion, stimulating proliferation and inhibiting apoptosis of pancreatic beta-cells ${ }^{14}$. Laferrère et al. ${ }^{7}$ determined that higher secretion and increased action of incretins was present after RYGB, which they attributed to faster glucose delivery to the small intestine.

DM2 improvement after RYGB is also related to higher insulin sensitivity due to a rise in adiponectin levels, which is present in serum in a inversely proportional relation to total fat mass ${ }^{5,6}$. Mari et al. ${ }^{8}$ showed that lean subjects had better insulin sensitivity compared to obese ones. Despite this difference, after bilio-pancreatic diversion, obese subjects could attain a sensitivity comparable to the lean control group.

Rubino et al. ${ }^{11}$ suggested that DM2 improvement after obesity surgery could be due to a change in free fatty acids (FFA) metabolism. It is known that high serum FFA concentrations increase insulin resistance and inhibit insulin secretion in both animals and humans. In this context, since RYGB reduces both fasting and post-prandial serum FFA, this could contribute positively to insulin resistance control.

$A$ recent study ${ }^{1}$ evaluating subjects exposed to RYGB seven years after surgery reported a significantly lower total mortality, as well as DM2, cardiovascular and cancer-related deaths compared to obese subjects not exposed to surgical treatment. Mortality related to other causes (suicide, trauma, etc) was higher among the surgical group.

All things considered, despite the widely-known morbidity and mortality related to the RYGB surgical procedure $(13.6 \%$ and $0.5 \%$, respectively), several studies propose that running such risk is reasonable in light of its readily known clinical benefits and promise of sustained control of a chronic, progressive and lethal disease such as DM2 ${ }^{15}$.

\section{CONCLUSION}

In PO1, weight loss and metabolic improvement was seen in both groups. This was sustained in PO3, with no significant weight regain or lipid/FG change. A1c found suggests a reasonable control of DM2 surgery. A trend towards a less intense weight loss could be noticed in the DM2 group.

\section{REFERENCES}

1. Adams TD, Gress RE, Smith SC, Halverson RC, Simper SC, Rosamond WD, LaMonte J, Stroup AM, Hunt SC. Long-Term Mortality after Gastric Bypass Surgery. N Engl J Med. 2007 Aug 23;357(8):753-61.

2. Belle SH, Chapman W, Courcoulas AP. Perioperative Safety in the Longitudinal Assessment of Bariatric Surgery. N Engl J Med. 2009 Jul 30;361(5):445-54.

3. Briatore L, Salani B, Andraghetti G, Danovaro C, Sferrazzo E, Scopinaro N, Adami GF, Maggi D, Cordera R. Restoration of Acute Insulin Response in T2DM Subjects 1 Month After Biliopancreatic Diversion. Obesity 2008 Jan;16(1):77-81.

4. Buchwald H, Avidor $Y$, Braunwald E. Bariatric Surgery: A Systematic Review and Meta- analysis. JAMA. 2004 Oct 13;292(14):1724-37.

5. Cummings DE, Overduin J, Foster-schubert KE. Gastric Bypass for Obesity: Mechanisms of Weight Loss and Diabetes Resolution. J Clin Endocrinol Metab 2004 89(6):2608-2615

6. Cummings DE. Endocrine mechanisms mediating remission of diabetes after gastric bypass surgery. International Journal of Obesity (Lond). 2009 Apr;33 Suppl 1:S33-40.

7. Laferrère $B$, Teixeira J, McGinty J, Tran H, Egger JR, Colarusso A, Kovack B, Bawa B, Koshy N, Lee H, Yapp K, Olivan B. Effect of Weight Loss by Gastric Bypass Surgery Versus Hypocaloric Diet on Glucose and Incretin Levels in Patients with Type 2 Diabetes. J Clin Endocrinol Metab 2008 Jul;93(7):2479-85.

8. Mari A, Manco M, Guidone C, Nanni G, Castagneto M, Mingrone $G$, Ferrannini E. Restoration of normal glucose tolerance in severely obese patients after bilio-pancreatic diversion: role of insulin sensitivity and beta cell function. Diabetologia 2006 Sep;49(9):2136-43.

9. Martins MVDC, Souza AAP. Mecanismos Cirúrgicos de Controle do Diabetes Mellitus tipo 2 após cirurgia bariátrica. Rev Col Bras Cir 2007 Set-Out; 34 (5): 343-346

10. Morínigo R, Lacy AM, Casamitjana R, Delgado S, Gomis R, Vidal J. GLP-1 and Changes in Glucose Tolerance following Gastric Bypass Surgery in Morbidly Obese Subjects. Obes Surg. 2006 Dec;16(12):1594-601.

11. Muscelli E, Mingrone G, Camastra S, Manco M, Pereira JA, Pareja JC, Ferrannini E. Differential effect of weight loss on insulin resistance in surgically treated obese patients. Am J Med. 2005 Jan;118(1):51-7.

12. Pories WJ. Bariatric Surgery: Risks and Rewards. J Clin Endocrinol Metab. 2008 Nov;93(11 Suppl 1):S89-96.

13. Robinson MK. Surgical Treatment of Obesity - Weighing the Facts. N Engl J Med. 2009 Jul 30;361(5):520-1. 
14. Rubino F, Forgione A, Cummings DE, Vix M, Gnuli D, Mingrone G, Castagneto M, Marescaux J. The Mechanism of Diabetes Control After Gastrointestinal Bypass Surgery Reveals a Role of the Proximal Small Intestine in the Pathophysiology of Type 2 Diabetes. Ann Surg. 2006 Nov;244(5):741-9.

15. Schauer FR, Burguera B. Effect of Lapaoscopic Roux-En Y Gastric Bypass on Type 2 Diabetes Mellitus. Ann Surg. 2003 Oct;238(4):467-84; discussion 84-5.

16. Shah M, Simha V, Garg A. REVIEW: Long-Term Impact of Bariatric Surgery on Body Weight, Comorbidities, and Nutritional Status. J Clin Endocrinol Metab. 2006 Nov;91(11):4223-31.
17.Sjöström L, Narbro, K, Sjöström, DC, Karason K, Larsson B, Wedel $H$, Lystig $T$, Sullivan M, Bouchard C, Carlsson B, Bengtsson C, Dahlgren S, Gummesson A, Jacobson P, Karlsson J, Lindroos A, Lönroth $\mathrm{H}$, Näslund I, Olbers T, Stenlöf K, Torgerson J, Ågren G, Carlsson, MSL. Effects of Bariatric Surgery on Mortality in Swedish Obese Subjects. N Engl J Med. 2007 Aug 23;357(8):74152.

18. Thaler JP, Cummings DE. Minireview: Hormonal and Metabolic Mechanisms of Diabetes Remission after Gastrointestinal Surgery. Endocrinology 2009 Jun;150(6):2518-25. 